\title{
PENGEMBANGAN PERANGKAT PEMBELAJARAN BERORIENTASI MODEL FLIPPED LEARNING PADA MATA KULIAH STATISTIKA
}

\author{
K.R. Winatha ${ }^{1}$, N.K.A.U. Dewi ${ }^{2}$ \\ ${ }^{12}$ Program Studi Teknik Informatika \\ STMIK STIKOM Indonesia \\ Denpasar, Indonesia
}

e-mail: $\underline{\text { redywin@stiki-indonesia.ac.id }}{ }^{1}$, anggra.uttari@stiki-indonesia.ac.id $^{2}$

\begin{abstract}
Abstrak
Di masa pendemi COVID-19, pemerintah mengeluarkan kebijakan untuk menerapkan pembelajaran daring. Hal ini tentunya, banyak menimbulkan permasalahan di perguruan tinggi, salah satunya adalah terjadi penurunan target kompetensi yang diharapkan disebabkan penerapan metode pembelajaran daring yang monoton. Guna mengatasi permasalahan tersebut, peneliti sebagai dosen mencoba menerapkan model pembelajaran inovatif flipped learning dalam pembelajaran daring mata kuliah statistika. Terpilinnya mata kuliah ini sebagai objek penelitian, karena sering digunakan dalam penyelesaian skripsi mahasiswa terutama dalam penentuan populasi dan sampel saat penyebaran kuesioner, materi yang cukup abstrak karena harus didukung dengan contoh-contoh dalam kehidupan sehari-hari, dan rencana pelaksanaan pembelajaran belum menyesuaikan dengan sistem pembelajaran secara daring. Namun, untuk mendukung pelaksanaan metode pembelajaran khususnya lipped learning, dibutuhkan suatu perangkat pembelajaran khusus. Penelitian ini merupakan penelitian pengembangan yang bertujuan menghasilkan produk berupa perangkat pembelajaran lipped learning pada mata kuliah statistika dengan menggunakan model ADDIE. Perangkat pembelajaran dengan model flipped learning telah berhasil dikembangkan, dan valid berdasarkan pengujian para ahli.
\end{abstract}

Kata kunci: Belajar di Rumah; Covid-19; Flipped Learning; Pembelajaran Daring

\begin{abstract}
During the COVID-19 pandemic, the government issued a policy to implement online learning. This, of course, causes many problems in universities, one of which is a decrease in the expected competency targets due to the application of monotonous online learning methods. In order to overcome these problems, researchers as lecturers tried to apply an innovative flipped learning model in online learning for statistics courses. This course was chosen as the object of research, because it is often used in completing student thesis, especially in determining the population and sample when distributing questionnaires, the material is quite abstract because it must be supported by examples in everyday life, and the learning implementation plan has not adjusted to the system. online learning. However, to support the implementation of learning methods, especially lipped learning, a special learning device is needed. This research is a development research that aims to produce a product in the form of a lipped learning learning device in statistics course using the ADDIE model. Learning devices with flipped learning models have been successfully developed, and are valid based on expert testing.
\end{abstract}

Keywords : Studying at Home; Covid-19; Flipped Learning; Online Learning

\section{PENDAHULUAN}

Sejak Maret 2020, pandemi mulai merubah seluruh tatanan kehidupan tak terkecuali pada dunia pendidikan.
Berdasarkan data UNESCO, akibat Covid-19 sekitar 98.4\% populasi siswa dunia telah dipengaruhi oleh penutupan sekolah (Nasir Mustafa, 2020). Masa pandemi Covid-19 membuat pola 
pendidikan Indonesia dan bahkan dunia mengalami perubahan akibat penutupan sekolah ini. Sebagai salah satu upaya guna mencegah penyebaran dan penularan virus Covid-19 di lingkungan satuan pendidikan, dan sesuai dengan Surat Edaran Sekretaris Jenderal Kementerian Pendidikan dan Kebudayaan Nomor 15 Tahun 2020 tentang Pedoman Penyelenggaraan Belajar dari Rumah dalam Masa Darurat Penyebaran Coronavirus Disease (Covid-19), Kemendikbud mengalihkan seluruh bentuk pelaksanaan pembelajaran secara tatap muka menjadi pembelajaran jarak jauh (PJJ) atau study from home (SFH).

$$
\text { Kegiatan study from home }
$$

dilaksanakan untuk memberikan pengalaman belajar yang bermakna bagi peserta didik, tanpa harus datang ke sekolah sebagai akibat dari pandemi. Salah satu hal yang dilakukan adalah pembelajaran daring supaya kegiatan belajar tetap berjalan. Pembelajaran daring (dalam jaringan) atau sebutan lainnya adalah pembelajaran online kini dijalankan sesuai kebijakan masing-masing lembaga pendidikan. Akibatnya, proses pembelajaran secara daring ini terlaksana sangat variatif dengan gaya masing-masing lembaga pendidikan.

Pembelajaran daring merupakan sistem pembelajaran yang dilakukan dengan tidak bertatap muka langsung, tetapi menggunakan bantuan platform-platform digital yang dapat membantu pembelajaran meskipun jarak jauh (Handarini \& Wulandari, 2020). Pembelajaran daring dengan segala kemudahan dan keunikannya menjadi pendekatan belajar yang paling efektif saat ini, namun bukan berarti tanpa masalah. Hal yang paling mendasar dan sekaligus menjadi momok yang tidak terpikirkan oleh banyak pihak penyelenggara pendidikan sesungguhnya bukanlah dari pihak peserta didik melainkan dari pihak pendidik (dosen). Seberapa siapkah dosen-dosen kita menyediakan pembelajaran online yang benar-benar efektif, dan efisien?
Berdasarkan hasil pengamatan
terhadap proses pembelajaran yang
dilakukan oleh dosen dan hasil diskusi
dengan beberapa dosen bahwa terjadi penurunan dan ketidaktercapaian target kompetensi yang diharapkan disebabkan penerapan metode pembelajaran daring yang kurang kreatif dan monoton. Selain itu, terlihat adanya kesenjangan antara peserta didik. Dimana, peserta didik kelompok atas nampak mendominasi dan lebih aktif dibandingkan peserta didik kelompok bawah. Hal ini disebabkan dosen belum mampu secara optimal dan belum siap dalam menempatkan posisi dan fungsi sebagai fasilitator (menjembatani pembelajaran), dinamisator (penggerak perubahan) dan pemberi dorongan (motivasi) proses pembelajaran daring.

Untuk mengatasi permasalahan di atas, dosen perlu menggunakan model pembelajaran inovatif salah satunya model pembelajaran flipped learning atau pembelajaran terbalik dalam pelaksanaan pembelajaran daring. Flipped learning atau ruang kelas terbalik adalah salah satu metode pembelajaran yang membalik proses pengajaran tradisional. Dibalik dalam arti bahwa jika sebelumnya dalam pembelajaran tradisional peserta didik mendengarkan penjelasan dosen di ruang kelas dan kemudian mengerjakan serangkaian masalah sebagai tugas rumah, metode flipped learning membaliknya di mana peserta didik membaca literatur dan mengasimilasi materi berupa video terlebih dahulu secara mandiri di rumah, kemudian dosen akan memandu menganalisis, dan memecahkan masalah yang dialami melalui diskusi (Nouri, 2016). Mengapa menggunakan metode flipped learning? Ada beberapa alasan mengapa dipilihnya metode ini berdasarkan hasil penelitian yang telah dilakukan sebelumnya, antara lain: (a) integrasi pembelajaran daring yang mengintegrasikan flipped learning menujukkan efek positif pada pembelajaran, perhatian, dan evaluasi peserta didik (Tang et al., 2020); (b) metode flipped learning 
meningkatkan motivasi dan kemandirian belajar, serta dapat menjadi alternatif pembelajaran pada masa pandemi Covid-19 (Hastuti, 2020); (c) pembelajaran daring dengan flipped learning dapat meningkatkan efektivitas belajar termasuk pembelajaran pengetahuan, keterampilan, dan keterlibatan peserta didik dalam pembelajaran (Yen, 2020); (d) Penerapan pembelajaran flipped learning dapat menjadi solusi pembelajaran yang efektif tanpa adanya kegiatan kelas tatap muka (Ibrahim \& Sukardjo, 2021).

Namun, untuk mendukung pelaksanaan metode pembelajaran khususnya flipped learning, dibutuhkan suatu perangkat pembelajaran khusus. Perangkat pembelajaran adalah sekumpulan sumber belajar yang memungkinkan pendidik dan peserta didik dapat melakukan kegiatan pembelajaran (Rando, 2017).

Berdasarkan beberapa penelitian yang telah dilakukan sebelumnya, perangkat pembelajaran yang digunakan untuk mendukung flipped learning adalah video. Terdapat beberapa manfaat dari penggunaan video baik dikelas offline maupun online, antara lain: (1) video lebih mudah diterima oleh peserta didik, video merupakan media yang paling sempurna yang dapat digunakan pendidik untuk memberikan pengetahuan baru; (2) merangsang aktivitas, video dapat memberikan stimulus dalam kegiatan pembelajaran di dalam kelas; (3) video membawa lebih banyak informasi, (4) video melibatkan pelajar; (5) video dapat mengintegrasikan dan membawa dunia luar ke dalam ruang kelas; (6) video dapat menceritakan sesuatu lebih dari hanya katakata; (7) video lebih fleksibel, dapat diberhentikan (pause), dapat dimundurkan (rewind), dan dapat diputar ulang (repeat); (8) dengan video semua lebih mudah dipahami, dan (9) video menciptakan pengalaman yang menyenangkan (Brown, 2021).

Berdasarkan permasalahan dan penelitian-penelitian terkait, peneliti mencoba memberikan alternatif sistem pembelajaran yang dapat diterapkan oleh dosen dengan mengembangkan perangkat pembelajaran berorientasi model flipped learning pada mata kuliah statistika. Perangkat pembelajaran yang dihasilkan terbatas pada rencana pembelajaran semester (RPS) dan video pembelajaran. Tujuan penelitian pengembangan ini adalah menghasilkan produk berupa perangkat pembelajaran flipped learning pada mata kuliah statistika yang telah divalidasi oleh para ahli.

\section{METODE}

Model pengembangan yang digunakan adalah model ADDIE, merupakan suatu pendekatan yang membantu dalam perancangan dan pengembangan produk-produk pembelajaran (Aldoobie, 2015). Model ini terdiri dari lima tahap pengembangan, yaitu: analyze, design, development, implementation dan evaluation. Model ini dipilih atas pertimbangan karena disajikan secara sederhana dan sistematik jika dibandingkan dengan model lainnya. Sifatnya terstruktur, sederhana dan sistematis, membuatnya sangat mudah digunakan dan diterapkan (Cheung, 2016). Dalam penelitian ini, tahapan yang dilakukan terbatas sampai pada tahap pengembangan (development). 


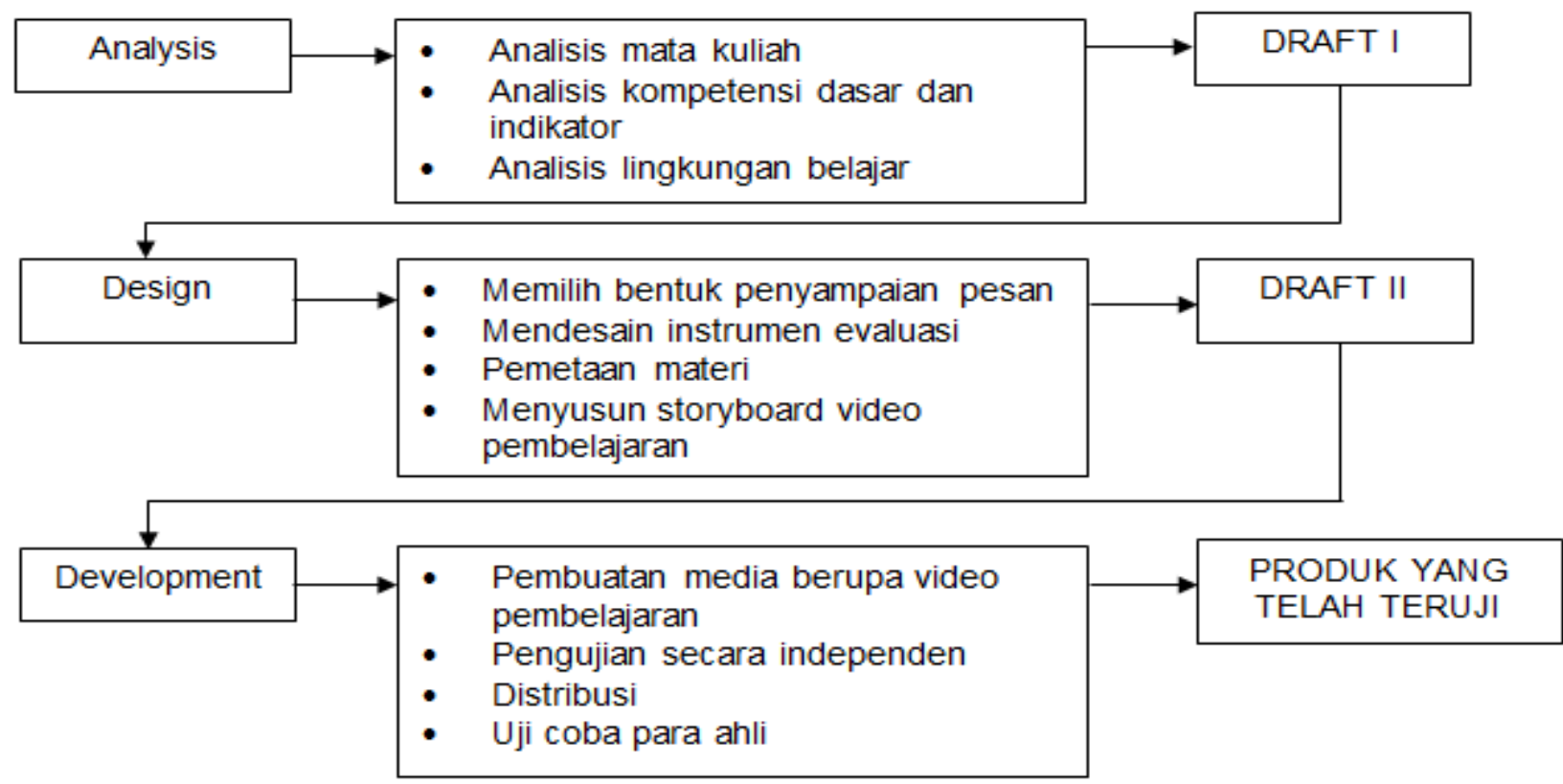

Gambar 1. Tahapan Pengembangan

Tahap Analysis. Kegiatan yang dilakukan oleh pengembang dalam tahap analisis yaitu: mendefinisikan masalah, mengindentifikasi sumber masalah, dan menentukan kemungkinan solusi dari permasalahan tersebut (Muruganantham, 2015). Pada tahap ini, terdapat beberapa kegiatan yang dilakukan yang bersifat deskriptif. Pertama, analisis mata kuliah. Dilakukan untuk mengetahui masalah serta kebutuhan yang diperlukan mata kuliah yang dijadikan sebagai objek pengembangan. Kedua, analisis kompetensi dasar dan indikator. Analisis kompetensi dasar, dan indikator hasil belajar berdasarkan struktur kurikulum dan silabus mata kuliah. Ketiga, analisis lingkungan belajar. Hasil seluruh kegiatan dalam tahap analisis, selanjutnya dijadikan sebagai acuan dalam proses pengembangan media sebelum dilanjutkan ke tahap berikutnya yaitu tahap desain (design).
Tahap Design. Terdapat beberapa kegiatan yang dilakukan pada tahap ini, antara lain: (a) memilih bentuk penyampaian materi; (b) mendesain instrumen evaluasi guna mengukur

keberhasilan pengembangan perangkat pembelajaran; (c) pemetaan materi; dan (d) menyusun storyboard video pembelajaran. Hasil yang diperoleh dalam tahap desain meliputi instrumen evaluasi produk, pemetaan materi, dan storyboard video yang kemudian digunakan sebagai garis besar sebelum dilanjutkan pada tahap berikutnya tahap pengembangan (development).

Tahap Development. Tahap ini terdiri dari kegiatan perwujudan media pembelajaran yaitu: (a) pengembangan rencana pembelajaran semester (RPS); (b) pembuatan media berupa video pembelajaran berdasarkan konsep yang 
telah direncanakan pada tahap desain; (c) pengujian secara independen. Produk yang telah selesai dikembangkan selanjutnya diuji secara independen oleh pengembang sendiri. Pengujian ini dilakukan untuk mencari berbagai kesalahan seperti kesalahan penulisan materi hingga kesalahan urutan maupun penempatan komponen-komponen pendukung ilustrasi berupa gambar; (d) distribusi. Media pembelajaran yang telah selesai dikembangkan dan telah diujikan secara independen, selanjutnya diperbanyak (direproduksi kembali) dan didistribusikan kepada pengguna dalam rangka evaluasi. Evaluasi dilakukan kepada tiga orang ahli dalam pengembangan media pembelajaran. Data dalam uji coba ahli diperoleh dengan menggunakan instrumen angket untuk mengetahui kualitas media yang dikembangkan. Evaluasi dari para ahli ini merupakan masukan terhadap kualitas media pembelajaran yang dikembangkan untuk selanjutnya dilakukan revisi sehingga pada akhirnya diperoleh produk yang valid.

\section{HASIL DAN PEMBAHASAN}

Tahap analysis terdiri dari tiga kegiatan yaitu analisis mata kuliah, analisis kompetensi dasar, dan analisis lingkungan belajar. Objek pengembangan dalam penelitian ini adalah mata kuliah statistika. Statistika merupakan bagian dari yang diwajibkan pada semua program studi STMIK STIKOM Indonesia. Pemilihan mata kuliah ini didasari oleh beberapa pertimbangan, yaitu: (a) sering digunakan dalam penyelesaian skripsi mahasiswa terutama dalam penentuan populasi dan sampel saat penyebaran kuesioner; (b) materi yang cukup abstrak karena harus didukung dengan contoh-contoh dalam kehidupan sehari-hari untuk menambah pemahaman. Ditambah lagi dengan keadaan pandemi dimana seluruh proses pembelajaran harus dilakukan secara daring; dan (c) rencana pelaksanaan pembelajaran belum menyesuaikan dengan sistem pembelajaran secara online. Hasil wawancara terhadap dosen mata kuliah statistika, didapatkan hasil bahwa sumber belajar yang digunakan oleh dosen hanya berupa slide presentasi yang materinya sebagian besar diperoleh dari internet. Mahasiswa tidak memiliki panduan belajar baik berupa modul cetak, maupun media pembelajaran mandiri yang dapat membantu mahasiswa dalam proses pembelajaran daring. Langkah kedua, dilanjutkan dengan melakukan analisis tehadap kompetensi dasar dan indikator hasil belajar berdasarkan silabus. Kompetensi dasar yang dijadikan fokus dalam penelitian ini adalah mahasiswa mampu memahami tentang hakikat dan fungsi statistika serta memahami tentang populasi dan sampel. Langkah ketiga, analisis lingkungan belajar. Dikarenakan masih dalam situasi pandemi COVID-19, maka lingkungan belajar masih sepenuhnya daring dengan memanfaatkan Google Classroom. Lingkungan belajar sangat berperan penting dalam menentukan keberhasilan pembelajaran daring di era COVID-19, sebab pembelajaran akan terlaksana dengan baik jika didukung oleh lingkungan belajar yang kondusif dan efisien (Galuh Asprilia Fadhilah, 2020).

Tahap design akan dilakukan beberapa kegiatan. Pertama, memilih bentuk penyampaian materi. Bentuk penyampaian materi dibantu dengan menggunakan video. Video dapat mengakomodasi keterlibatan dan menginspirasi ketika digunakan dalam pembelajaran yang berpusat pada peserta didik, meningkatkan motivasi, peningkatan otonomi peserta didik, dan memperluas potensi untuk lebih dalam memahami konsep mata pelajaran (Beheshti, Taspolat, Kaya, \& Sapanca, 2018). Kedua, mendesain instrumen evaluasi. Karena tahap penelitian terbatas hanya pada tahap pengembangan maka, instrumen yang digunakan dalam mengukur keberhasilan pengembangan 
media adalah berupa angket uji ahli. Angket uji ahli yang dibuat terdiri dari angket untuk ahli isi, ahli media, dan ahli desain pembelajaran. Ketiga, pemetaan materi yang akan dijadikan fokus pengembangan. Pemetaan ini penting dilakukan untuk mengetahui gambaran umum materi apa saja yang harus disampaikan. Pada tahap ini, unsur-unsur pendukung yang akan disajikan pada tiap kompetensi diorganisasikan secara tepat dan cermat agar sesuai dengan tujuan pembelajaran yang ingin dicapai.

Tahap development merupakan tahap perwujudan perangkat pembelajaran setelah dua tahap sebelumnya yaitu tahap analisis dan desain selesai dilaksanakan. Kegiatan yang dilakukan pada tahap ini antara lain: Pertama, mendesain rencana pembelajaran semester. Pada penelitian ini, terbatas pada dua indikator pembelajaran ditunjukkan pada Tabel 1.

Tabel 1. Desain Rencana Pembelajaran Semester (RPS)

\begin{tabular}{|c|c|c|c|c|}
\hline No & $\begin{array}{l}\text { Kemampuan Akhir } \\
\text { yang Diharapkan }\end{array}$ & $\begin{array}{c}\text { Materi } \\
\text { Pembelajaran }\end{array}$ & $\begin{array}{l}\text { Bentuk Pembelajaran, } \\
\text { Metode Pembelajaran, } \\
\text { Estimasi Waktu }\end{array}$ & $\begin{array}{l}\text { Pengalaman } \\
\text { Belajar }\end{array}$ \\
\hline 1 & $\begin{array}{l}\text { Mahasiswa mampu } \\
\text { memahami tentang } \\
\text { hakikat dan fungsi } \\
\text { statistika }\end{array}$ & $\begin{array}{l}\text { 1. Statistik dan } \\
\text { statistika } \\
\text { 2. Hakikat } \\
\text { statistika } \\
\text { 3. Jenis statistika } \\
\text { 4. Fungsi } \\
\text { statistika }\end{array}$ & $\begin{array}{l}\text { Lingkungan belajar: } \\
\text { Google Classroom } \\
\text { Bentuk Perkuliahan : } \\
\text { Synchronous, } \\
\text { Asynchronous } \\
\text { Metode } \\
\text { Pembelajaran: } \\
\text { Flipped Learning } \\
\text { Media } \\
\text { Video pembelajaran } \\
\text { Waktu: } \\
\mathrm{T}=(1 \times(2 \times 50 ")) \\
\mathrm{P}=0\end{array}$ & $\begin{array}{l}\text { Mahasiswa pada } \\
\text { saat proses } \\
\text { belajar } \\
\text { menjabarkan } \\
\text { mengenai konsep } \\
\text { statistik dan } \\
\text { statistika, } \\
\text { menjelaskan } \\
\text { hakikat, jenis, dan } \\
\text { fungsi statistika } \\
\text { dalam kehidupan } \\
\text { sehari-hari }\end{array}$ \\
\hline 2 & $\begin{array}{l}\text { Mahasiswa mampu } \\
\text { memahami tentang } \\
\text { populasi dan } \\
\text { sampel, dan teknik } \\
\text { pemilihan sampel }\end{array}$ & $\begin{array}{l}\text { 1. Populasi dan } \\
\text { sampel } \\
\text { 2. Teknik-teknik } \\
\text { pemilihan } \\
\text { sampel }\end{array}$ & $\begin{array}{l}\text { Lingkungan belajar: } \\
\text { Google Classroom } \\
\text { Bentuk Perkuliahan : } \\
\text { Synchronous, } \\
\text { Asynchronous } \\
\text { Metode } \\
\text { Pembelajaran: } \\
\text { Flipped Learning } \\
\text { Media } \\
\text { Video pembelajaran } \\
\text { Waktu: } \\
\mathrm{T}=(1 \times(2 \times 50 ")) \\
\mathrm{P}=0\end{array}$ & $\begin{array}{l}\text { Mahasiswa pada } \\
\text { saat proses } \\
\text { belajar } \\
\text { menjelaskan } \\
\text { perbedaan } \\
\text { populasi dan } \\
\text { sampel, dan } \\
\text { mampu } \\
\text { menjabarkan } \\
\text { teknik-teknik } \\
\text { pemilihan sampel }\end{array}$ \\
\hline 12 & $\begin{array}{l}\text { Kedua, pengumpulan } \\
\text { dikumpulkan, dipilih } \\
\text { an kebutuhan mater } \\
\text { onen pendukung dala } \\
\text { i yaitu teks, gambar, } \\
\text { akan sebagai pe }\end{array}$ & $\begin{array}{l}\text { bahan. Bahan } \\
\text { an disesuaikan } \\
\text { pembelajaran. } \\
\text { n penyampaian } \\
\text { an audio. Teks } \\
\text { ddukung dan }\end{array}$ & \multicolumn{2}{|c|}{$\begin{array}{l}\text { pengulangan terhadap materi yang } \\
\text { disampaikan. Beberapa hal yang menjadi } \\
\text { perhatian dalam penggunaan teks yaitu: a) } \\
\text { gaya teks, b) ukuran, c) spasi, dan d) warna. } \\
\text { Gambar digunakan sebagai penjelas } \\
\text { visualisasi dari materi yang disajikan }\end{array}$} \\
\hline
\end{tabular}


dengan teks. Ketiga, pembuatan media. Keseluruhan desain media kartu dibuat dengan menggunakan perangkat lunak Adobe Premier dan Adobe AfterEffect.

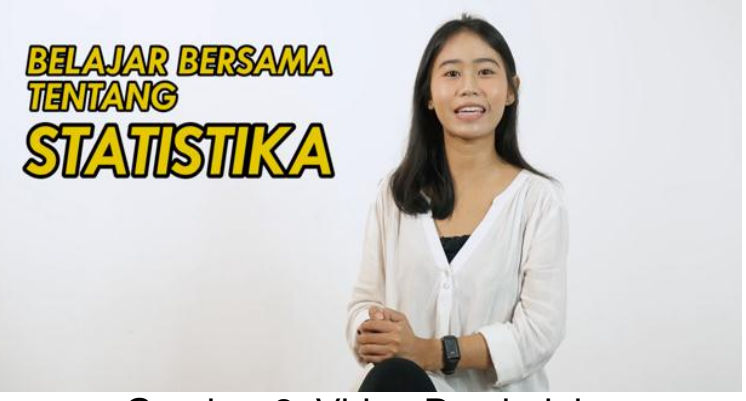

Gambar 2. Video Pembelajaran

Produk akhir pengembangan berupa video pembelajaran sesuai dengan kompetensi dasar yang ditargetkan.

\section{APA IIUU STAUISTLKAB \\ MTINGAPA BILLAVAB STEATSULIKAB

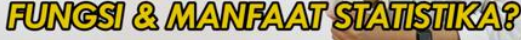

Gambar 3. Video Pembelajaran Materi Hakikat dan Fungsi Statistika

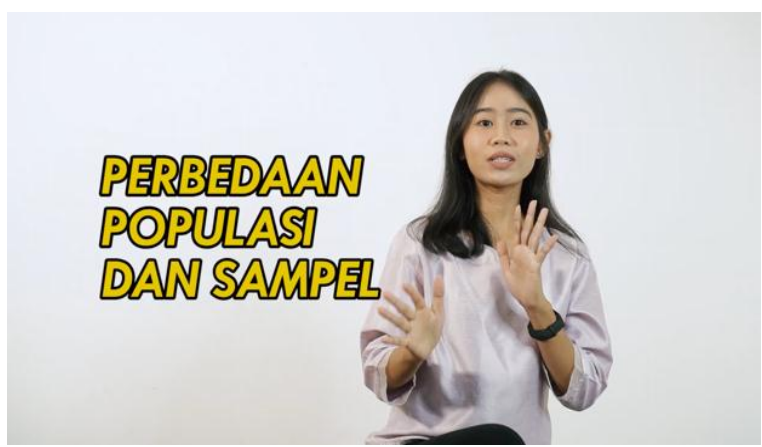

Gambar 4. Video Pembelajaran Materi Populasi dan Sampel

Keempat, pengujian independen. Produk yang telah dikembangkan selanjutnya diuji independen oleh pengembang Pengujian ini dilakukan untuk mencari berbagai kesalahan penulisan kata maupun gambar yang digunakan. Kelima, distribusi di mana produk pengembangan direproduksi kembali dan didistribusikan kepada pengguna dalam rangka evaluasi. Keenam, uji coba produk. Produk yang telah selesai dikembangkan selanjutnya diujikan kepada tiga ahli yaitu ahli isi, ahli desain pembelajaran, dan ahli media.

\section{Hasil uji}

Media telah melewati serangkaian uji ahli diantara ahli media, isi, dan desain. Hasil penilaian ahli media pembelajaran antara lain: Pertama, kesesuaian gambar yang digunakan dalam membantu memvisualisasikan materi. Penggunaan gambar yang tepat, memfasilitasi pengalaman belajar ketika gambar tersebut berhasil memfokuskan perhatian peserta didik secara visual dan sesuai dengan materi yang disampaikan (Smeets \& Bus, 2015).

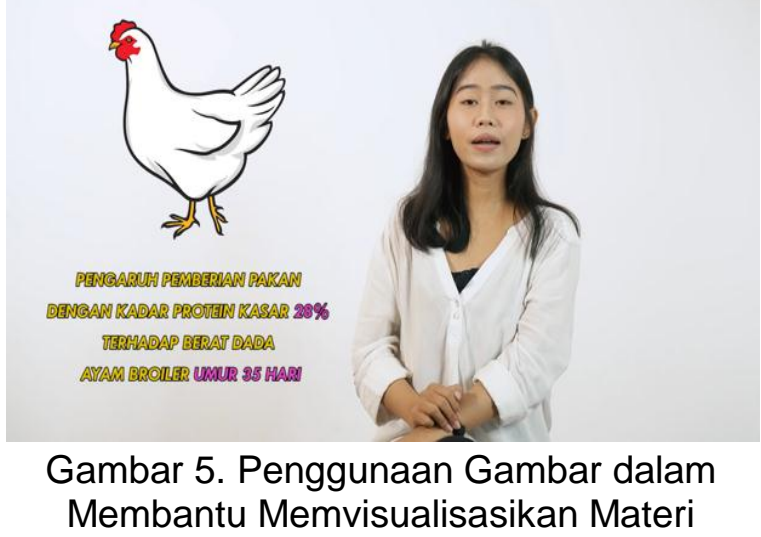

Kedua, media mudah digunakan dan memiliki fleksibiltas yang tinggi. Ketiga, media dikemas dengan visual yang menarik. Kualitas video yang tinggi, kejelasan audio, pengunaan warna pada teks, serta ketepatan penggunaan gambar menambah sisi menarik dari media pembelajaran.

Hasil penilaian ahli desain pembelajaran antara lain: Pertama, desain rencana pembelajaran semester (RPS) telah disesuaikan dengan model pembelajaran yang dipilih yaitu flipped 
learning. Kedua, dari aspek konten, materi yang disajikan lewat media telah sesuai dengan tujuan pembelajaran dan rencana pembelajaran semester (RPS). Ketiga, dari aspek strategi pengorganisasian isi, media telah mengandung pengulangan untuk memperkuat pemahaman, memicu peningkatan motivasi, serta pemilihan gambar membantu mempermudah pemahaman. Fungsi utama adanya pengulangan pada media pembelajaran adalah untuk memastikan peserta didik memahami persyaratan-persyaratan yang dituntut oleh suatu mata pelajaran. Peserta didik akan belajar dengan mudah dan mengingat lebih lama jika mereka mengulangi apa yang mereka pahami $(\mathrm{H}$. Gani Ali, 2014).
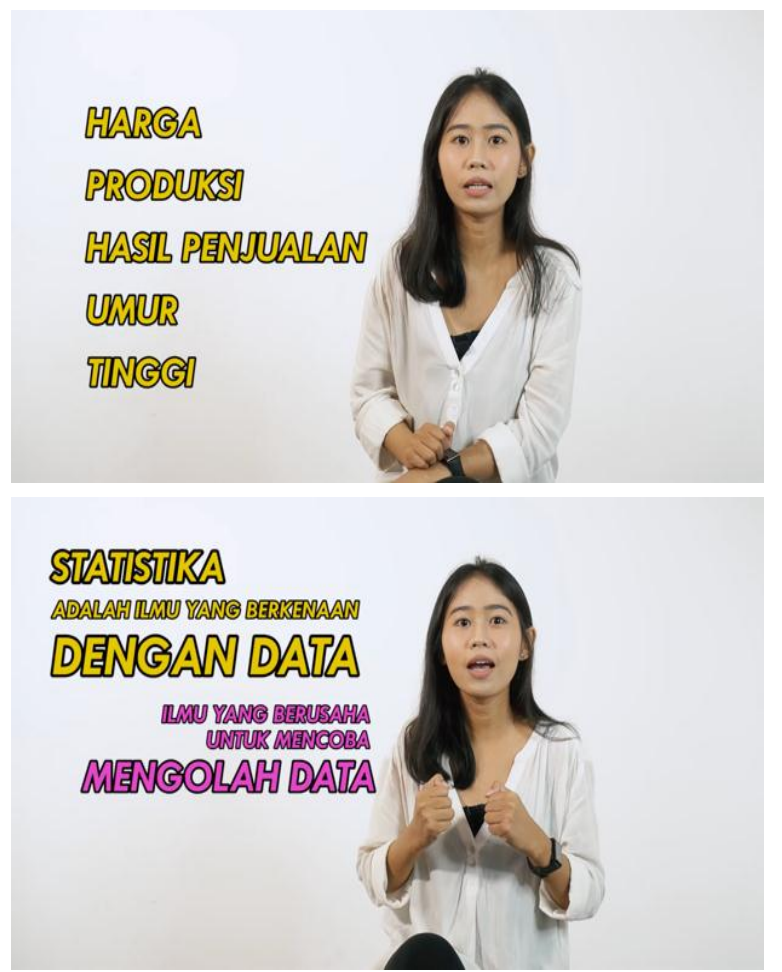

Gambar 6. Penggunaan Teks untuk Pengulangan Materi

Keempat, dari aspek penyampaian isi, materi yang disajikan lewat media disajikan secara sederhana dan jelas, membuat gagasan abstrak menjadi lebih kongkret, disajikan secara ringan inovatif untuk membangkitkan minat dan motivasi, untuk menunjang keterlibatan dan kemauan mahasiswa untuk terlibat aktif mengemukakan dan berbagi ide.

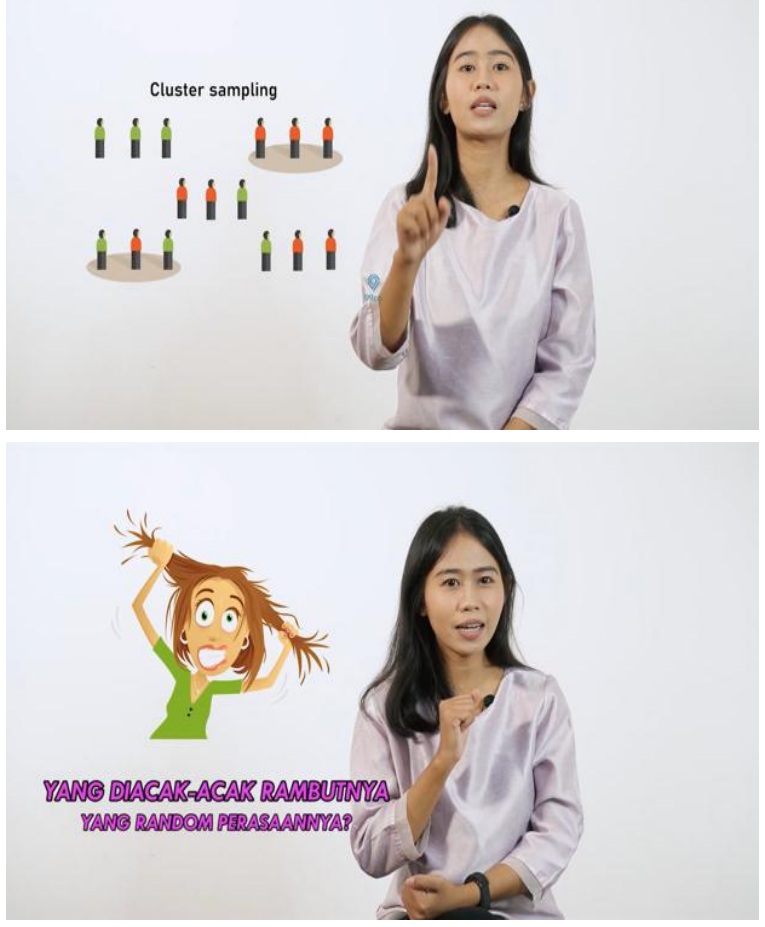

Gambar 7. Penyajian Menarik, Ringan, dan Inovatif untuk Mendukung Penyampaian Materi

Kelima, berdasarkan kemenarikan konsep media pembelajaran, desain tampilan media dinilai mampu menarik minat dan perhatian peserta didik untuk belajar.

Hasil penilaian ahli isi antara lain: Pertama, dari aspek cakupan dan akurasi materi, materi yang disajikan melalui media telah mencangkup materi yang ada dalam kurikulum. Keluasan materi sesuai dengan kompetensi dasar dan indikator dalam rencana pembelajaran semester (RPS). Serta ilustrasi yang digunakan berupa gambar sesuai dengan materi. Kedua, dari aspek produktivitas dan inovasi, media yang dikembangkan berpusat pada peserta didik, menyajikan contoh-contoh dalam pengalaman dan kehidupan sehari-hari (kontekstual), serta merangsang peserta didik untuk berfikir kritis, kreatif, dan inovatif dalam pemecahan masalah. Melalui 
pembelajaran kontekstual, pengalaman belajar bukan hanya terjadi dan dimiliki ketika peserta didik berada di dalam kelas, tetapi jauh lebih penting dari itu adalah bagaimana membawa pengalaman belajar tersebut keluar dari kelas untuk menanggapi dan memecahkan permasalahan yang nyata yang dihadapi sehari-hari (Kadir, 2013). Ketiga, dari aspek penyajian, pesan yang disampaikan melalui media mudah dipahami.
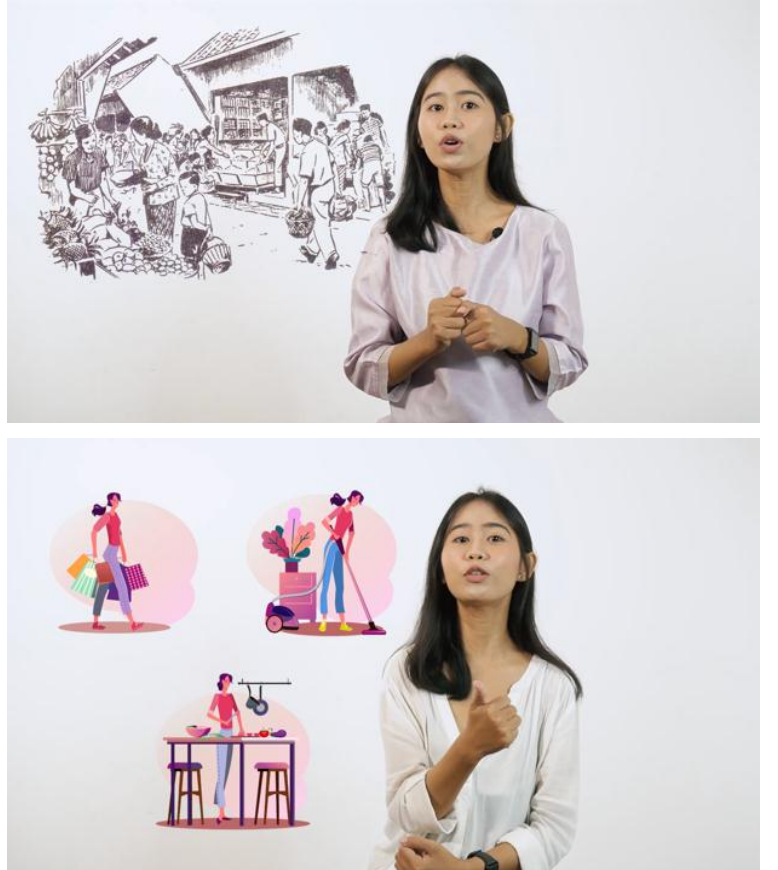

Gambar 8. Materi Disajikan dengan ContohContoh dalam Kehidupan Sehari-Hari

\section{PENUTUP}

Berdasarkan hasil pengujian para ahli yang telah dilakukan, perangkat pembelajaran dengan model flipped learning telah berhasil dikembangkan dan layak dilanjutkan pada tahap berikutnya yaitu tahap implementasi dan evaluasi untuk mengetahui pengaruh media terhadap motivasi dan hasil belajar mahasiswa.

Adapun saran yang dapat diberikan antara lain: (a) penelitian terbatas sampai pada tahap pengembangan dan produk yang dihasilkan hanya rencana pembelajaran semester (RPS) dan video pembelajaran. Perlu dikaji lebih jauh hingga tahap evaluasi untuk mengetahui keefektivitasan perangkat pembelajaran; (b) Pengembangan perangkat pembelajaran, hanya mencangkup mata kuliah statistika STMIK STIKOM Indonesia dan dua indikator pembelajaran. Bagi peneliti lain yang ingin mengembangkan media yang serupa, agar mengembangkannya pada mata kuliah lain; dan (c) Diharapkan kepada seluruh dosen pengampu mata kuliah statistika, dapat mengimplementasikan

pembelajaran ini dalam proses pembelajaran.

\section{DAFTAR PUSTAKA}

Aldoobie, N. (2015). ADDIE Model Analysis phase. American International Journal of Contemporary Research. https://doi.org/10.13140/2.1.4687.616 9

Beheshti, M., Taspolat, A., Kaya, O. S., \& Sapanca, H. F. (2018). Charateristics of Educational Videos. World Journal on Educational Technology, 10(1), 61-69. Retrieved from https://files.eric.ed.gov/fulltext/EJ1170 366.pdf

Brown, L. (2021). Benefits for Teacher Using Video in the Classroom. Retrieved September 3, 2021, from https://filmora.wondershare.com/video -editing-tips/benefits-for-using-videoin-classroom.html

Cheung, L. (2016). Using the ADDIE Model of Instructional Design to Teach Chest Radiograph Interpretation. Journal of Biomedical Education, 2016, 1-6. https://doi.org/10.1155/2016/9502572

Galuh Asprilia Fadhilah. (2020). The role of the learning environment in addressing online learning in the Covid-19 era. Biormatika: Jurnal IImiah Fakultas Keguruan Dan IImu Pendidikan, 6(02), 106-116. https://doi.org/10.35569/biormatika.v6i 02.772 
H. Gani Ali. (2014). Prinsip-prinsip Pembelajaran dan Implikasinya Terhadap Pendidik dan Peserta didik. Jurnal Al-Ta'dib, 6(1), 31-42.

Handarini, O. I., \& Wulandari, S. S. (2020). Pembelajaran Daring Sebagai Upaya Study From Home (SFH) Selama Pandemi Covid 19. Jurnal Pendidikan Administrasi Perkantoran (JPAP), 8(3), 496-503.

Hastuti, W. D. (2020). Membangun Motivasi dan Kemandirian Peserta Didik Berkebutuhan Khusus Melalui Flipped Classroom di Masa New Normal Covid-19. Prosiding Webinar Magister Pendidikan Nonformal UNG, (September), 181-192.

Ibrahim, N., \& Sukardjo, M. (2021). How Flipped Classroom Helps the Learning in the Times of Covid-19 Era? Jurnal Teknologi Pendidikan, 22(July 2020), 151-158.

Kadir, A. (2013). Konsep Pembelajaran Kontekstual di Sekolah. Dinamika IImu, 13(1), 17-38. Retrieved from http://journal.iainsamarinda.ac.id/index.php/dinamika_il $\mathrm{mu} /$ article/view/20

Muruganantham, G. (2015). Developing of E-content package by using ADDIE model. ljar.

Nasir Mustafa. (2020). Impact of the 2019 20 coronavirus pandemic on education. International Journal of Health Preferences Research, 1-36.

Nouri, J. (2016). The flipped classroom: for active, effective and increased learning - especially for low achievers. International Journal of Educational Technology in Higher Education, 13(1), 13-33. https://doi.org/10.1186/s41239-0160032-z

Rando, A. R. (2017). Pengembangan Perangkat Pembelajaran dalam Implementasi Strategi Contextual
Teaching Learning untuk Meningkatkan Hasil Belajar IPS Pokok Bahasan Perkembangan Teknologi pada Siswa Kelas IV SD. Jurnal Pendidikan (Teori Dan Praktik), 1(1), 1. https://doi.org/10.26740/jp.v1n1.p112

Smeets, D. J. H., \& Bus, A. G. (2015). The interactive animated e-book as a word learning device for kindergartners. Applied Psycholinguistics. https://doi.org/10.1017/S01427164130 00556

Tang, T., Abuhmaid, A. M., Olaimat, M., Oudat, D. M., Aldhaeebi, M., \& Bamanger, E. (2020). Efficiency of flipped classroom with online-based teaching under COVID-19. Interactive Learning Environments, O(0), 1-12. https://doi.org/10.1080/10494820.202 0.1817761

Yen, T.-F. (2020). The Performance of Online Teaching for Flipped Classroom Based on COVID-19 Aspect. Asian Journal of Education and Social Studies, 8(3), 57-64. https://doi.org/10.9734/AJESS/2020/v $8 i 330229$ 